\title{
Experimental investigations on the performance and emissions characteristics of dual biodiesel blends on a varying compression ratio diesel engine
}

\author{
Navdeep Sharma Dugala ${ }^{1} \cdot$ Gyanendra Singh Goindi ${ }^{1}$ Ajay Sharma ${ }^{1}$
}

Received: 2 November 2020 / Accepted: 29 April 2021

Published online: 11 May 2021

(c) The Author(s) $2021 \quad$ OPEN

\begin{abstract}
The present work discusses the performance and emissions characterization of dual biodiesel sample blends on a varying compression ratio diesel engine. The dual biodiesel blends were obtained by blending two biodiesels (Mahua and Jatropha) in equal proportions volume $(1: 1, \mathrm{v} / \mathrm{v})$ with mineral diesel. The sample blends were obtained on a'percentage by volume' basis and named B10, B20, B30, and B40 (B10 was a blend of 5\% each biodiesel with 90\% mineral diesel and similarly for all other sample blends). All the experiments were performed at a constant engine speed of $1500 \mathrm{rpm}, 50 \%$ loading conditions (2.6 kW), and varying compression ratios of 13.5:1, 14.5:1, 15.5:1, and 16.5:1. The results revealed that the sample blends had slightly higher brake power and mechanical efficiency with sample blends B10 to B40 had (0.15-1.58\%) higher brake power and (1.07-12.42\%) higher mechanical efficiency as compared to mineral diesel at a compression ratio of 16.5:1. The In-cylinder peak pressure and exhaust gas temperature were observed to be lower than mineral diesel for the sample blends B10 to B40 by $0.15-0.36$ bar and 11.1-69.8 ${ }^{\circ} \mathrm{C}$, respectively. Also, the emissions of carbon monoxide and hydrocarbons were lower by $33-62 \%$, respectively, for the sample with the highest blend percentage. However, the carbon dioxide emissions were found to be higher by $42.85 \%$ than mineral diesel. From the overall performance and characterization, it is concluded that B20 had optimum properties and blend percentage to be a better substitute fuel for mineral diesel among all the tested samples.
\end{abstract}

Keywords Mahua and Jatropha biodiesel · Dual biodiesel - Engine performance - Combustion characteristics · Exhaust emission properties - Variable compression ratio

\begin{tabular}{llll}
\multicolumn{2}{l}{ Abbreviations } & $\mathrm{CO}$ & Carbon monoxide \\
FFA & Free fatty acids & $\mathrm{CO}_{2}$ & Carbon dioxide \\
VCR & Varying compression ratio & $\mathrm{NO}_{x}$ & Nitrogen oxides \\
BP & Brake power & $\mathrm{PPM}$ & Parts per million \\
CR & Compression ratio & $\mathrm{BTE}$ & Brake thermal efficiency \\
BTDC & Before top dead center & $\mathrm{SPM}$ & Specific particulate matter \\
ME & Mechanical efficiency & & \\
BSFC & Brake-specific fuel consumption & & \\
In-CPP & In-cylinder peak pressure & & \\
EGT & Exhaust gases temperature & & \\
HC & Hydrocarbons & &
\end{tabular}

Navdeep Sharma Dugala, navdeepdugala@gmail.com | ${ }^{1}$ Chandigarh University, SAS Nagar, Punjab, India.

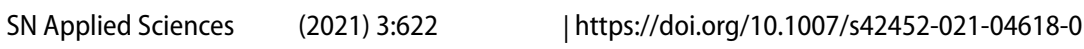




\section{Introduction}

Indigenously available energy resources play a significant role in the economic growth of a country. These resources are also important for the sustainability of a developing country. According to a report given by the Department of Energy, USA, the demand for crude oil will reach its peak by the end of this century and the fossil fuel reserves might reduce to a fractional value of their current estimates. Lately, the extensive use of petroleum products due to the rise in industry and the human population has led to the exhaustion of crude oil reserves (US Department, https://www.eia.gov/). The higher demand leads to a rise in the higher price of fossil fuels [10]. Globally, people consume more than 11 billion tons of oil from fossil fuels each year. The reserves for crude oil are declining at a very high rate of 4 billion tons per year approximately, and at this rate, the stocks of oil reserves may get depleted in just another four to five decades. Highly populated countries like China and India are consuming the maximum amount of aviation fuel [50]. Further, the emissions of harmful gases like carbon monoxide, hydrocarbons, carbon dioxide, and particulate matter are the direct result of the worldwide combustion of petroleum products. The use of fossil fuels contributes about $25 \%$ to the total greenhouse gas emissions [25]. Due to the above-mentioned reasons, finding alternate energy resources has become a necessity for researchers all over the world.

Many researchers around the globe did intensive research on biodiesels that has the potential to provide a possible way out to substitute conventional diesel at lower prices [30]. Biodiesel can be obtained from edible or non-edible vegetable and animal fat oil. It is produced by various methods like pyrolysis, emulsification, blending, and trans-esterification. However, the most commonly used method for producing biodiesel is transesterification since it is the most economical method among all $[3,6]$.

Mahua and Jatropha raw seed oil have prominent free fatty acid (FFA) content, which is around 19-23\% [13]. It is possible to reduce the FFA of raw oil with a suitable pre-treatment process. The production of biodiesel from raw oil depends upon various parameters like reaction temperature, category of catalyst used, the ratio of oil to alcohol used, and purity of the reactants $[1,5]$.

The physicochemical properties such as iodine value, acid value, fire point, and flash point, kinematic viscosity, density, etc. make it suitable to be used as biodiesel, but its cold flow properties are still a matter of concern [20]. Contrary to Mahua biodiesel, Jatropha biodiesel has good cold flow properties. Mahua and Jatropha biodiesel also have better combustion and emissions properties. To enhance the physicochemical properties of individual biodiesel, dual biodiesel can be prepared by the blending of these two. It was reported that preheating of Jatropha oil can help to reduce its kinematic viscosity and enhance its fuel atomization for biodiesel $[3,8,21]$. Preheating of raw palm oil (up to $90{ }^{\circ} \mathrm{C}$ ) improved its density and viscosity, which in turn improves its flow properties and reduces the clogging problem of fuel injectors and fuel filters [12]. It has been reported by many researchers that the blending of biodiesel in diesel fuel can help to reduce the engine emissions to a great extent in comparison with the emissions given by the combustion of currently used diesel fuel $[40,51]$. Chauhan et al. have stressed the recommendation of biodiesel prepared from Jatropha oil as a fuel and reported its engine performance, variation in combustion, and emission properties [15]. Solaimuthu and Govindarajan [53] examined Mahua oil biodiesel blend with diesel and observed that $25 \%$ blend had the lowest hydrocarbons and nitrogen oxides emissions with 100\% loading conditions. A review of the literature of some researchers is presented in Table 1.

From the review of the works of literature, it is evident that extensive research has been done to determine the efficiency of engine and emissions of exhaust gases for various blended biodiesels with mineral diesel at constant $C R$, but only a few articles are available on the diesel engine output parameters using dual biodiesel blended with mineral diesel at VCR $[2,3,21,27]$.

The studies mentioned above were carried out in engines with different specifications and using biodiesels prepared from various first-generation or second-generation vegetable oils. In these studies, the effect of varying parameters has been emphasized by all researchers on engine combustion, engine performance, and emissions characteristics $[26,43,54,61]$. However, it is worth noting that studies on dual biodiesel prepared by mixing different biodiesels with mineral diesel were found to be limited. All previous researches on the physical and chemical characterization of dual biodiesel prepared by mixing of different biodiesel with mineral diesel in various proportions revealed that these sample blends might become a suitable candidate to replace mineral diesel $[16,18,29$, 37]. Therefore, it is highly significant to measure the different characteristics of dual biodiesel on a VCR engine to check its emission properties and engine performance parameters.

Although biodiesel has a strong potential to replace conventional diesel, it has many underlying problems associated with it such as high viscosity, choking of nozzles in fuel injectors, carbon deposition inside the engine cylinder, free fatty acid content, etc. [21]. To overcome 
Table 1 Literature survey from different authors

\begin{tabular}{ll}
\hline S. No & Feedstocks \\
\hline 1 & $\begin{array}{c}\text { Spirulina microalgae, ethanol, } \\
\text { methanol, and diesel (base fuel) }\end{array}$
\end{tabular}

Research findings/ Outcomes

It was observed that EBT of hybrid fuel (ethanol) emulsions were high and EGT

was low compared with diesel

Engine emission results show that spirulina microalgae emulsions fuel reduces the SPM, smoke emissions, and soot except for $\mathrm{NOx} \& \mathrm{CO}_{2}$ compared with diesel fuel

$2 \quad$ Not mentioned

Citronella oil and biodiesel blends (KB10 and RB10)

Roselle biodiesel
The author did a detailed review on trending modeling methods such as Analytical methods

Regression methods

The review recommends combining advanced statistical methods and emerging popular machine learning algorithms to engine research for deriving comprehensive pragmatic models as an empirical compromise

The optimum IAT was found to be $90^{\circ} \mathrm{C}$, so further experiments were carried out using the IAT $90^{\circ} \mathrm{C}$ at various EGR ratios

The EGR-associated $\mathrm{HCCl}$ engine produces ultra-lean NOx emissions, slightly lower BTE, cylinder pressure, and heat release rate than the engine operating without EGR. The results also showed that a rise in IAT above $100^{\circ} \mathrm{C}$ leads to short $\mathrm{HCCl}$ combustion, inclining to knock, thus leading to unstable operation

The biodiesel was prepared with diesel on a volume basis, namely B20, B40, and $\mathrm{B} 60$, and examined on a 1-cylinder $\mathrm{Cl}$ diesel engine

The BTE of citronella oil and its blend were found lower than diesel, and compared to all blend samples, the B20 blend had better efficiency. The B20 (20\% Citronella oil $+80 \%$ Diesel) appealed $1.47 \%$ lower in engine BTE and $2.7 \%$ higher fuel consumption than diesel fuel

The smoke emissions of biodiesel lowered by $31 \%$ than diesel fuel, with a negligible rise in $\mathrm{NOx}$ and $\mathrm{CO}_{2}$ emission by $12.5 \%$ and $7.1 \%$, respectively. Besides that, $\mathrm{CO}$ and $\mathrm{HC}$ were $16.34 \%$ and $22.2 \%$ lower than diesel fuel when the engine was running at higher load conditions

The engine performance at different engine loads at constant speed was tested for prepared biodiesel. It was observed that In-CPP, BTE, EGT, ignition delay, and indicated thermal efficiency were reduced by $4.93,4.3,1.2,2.47$, and $0.71 \%$ for LA20 (20\% Roselle + 80\% Diesel) sample blend when compared with mineral diesel

BTE, EGT, $\mathrm{NO}_{x}$, and smoke emissions were reduced by $1.84 \%, 1.62 \%, 3.84 \%$, and $13.53 \%$, respectively, while BSFC was escalated up to $8.6 \%$ for KB20 ( $20 \%$ Karanja $+80 \%$ Diesel)

The dual biodiesel was prepared by blending with diesel fuel

The engine performance showed that the BTE was reduced and BSFC was increased for both RB10 and KB10 compared to diesel

The author analyzed B20, B40, and B100 sample blends of Roselle biodiesel on a diesel engine by changing the injection pressure during fuel injection and engine loading and compared it with mineral diesel

It was found that smoke emission, thermal efficiency, ignition delay period, and indicated efficiency were reduced while mean effective pressure, In-cylinder peak pressure, $\mathrm{CO}_{2}$, and $\mathrm{NO}_{\mathrm{x}}$ emissions increased at high fuel injection pressure

The indicated mean effective pressure, brake power, mechanical efficiency, and emissions of exhaust gas by varying compression ratios on palm biodiesel blended with diesel were investigated

The study revealed that for higher compression ratios, $20 \%$ blend sample produces around $6 \%$ higher brake power and $14.6 \%$ higher mechanical efficiency compared with diesel. EGT was found to be lower for all blends. At $100 \%$ loading conditions, $\mathrm{HC}$ and $\mathrm{CO}$ content in exhaust gas was reduced by increasing the compression ratio and blend percentage. However, $\mathrm{CO}_{2}$ content in exhaust gas was found to be more than diesel 
Table 1 (continued)

\begin{tabular}{|c|c|c|c|}
\hline S. No & Feedstocks & Research findings/ Outcomes & References \\
\hline \multirow[t]{2}{*}{9} & \multirow[t]{2}{*}{ Waste cooking oil and mineral diesel } & $\begin{array}{l}\text { The fuel combustion characteristics of blends of diesel in various proportions } \\
\text { with biodiesel prepared from the second-generation waste cooking oil through } \\
\text { a two-step trans-esterification process }\end{array}$ & \multirow[t]{2}{*}[24]{} \\
\hline & & $\begin{array}{l}\text { A 4-stroke VCR; a 1-cylinder engine was used for the experimentation research } \\
\text { work. The results revealed that increased CR (from } 14 \text { to 18) gave higher BTE (up } \\
\text { to } 27.48 \% \text { ), reduced } \mathrm{HC} \text { and } \mathrm{CO}(52 \% \text { and } 37.5 \%) \text { in the exhaust. However, the } \\
\text { percentage of } \mathrm{CO}_{2} \text { and NOx emissions came out } 36.84 \% \text { and } 14.28 \% \text { higher, as } \\
\text { compared to mineral diesel }\end{array}$ & \\
\hline \multirow[t]{2}{*}{10} & \multirow[t]{2}{*}{ Cottonseed oil } & $\begin{array}{l}\text { Authors worked on cottonseed oil biodiesel prepared by preheating and trans- } \\
\text { esterification at various temperature ranges (like } 50,70 \text {, and } 90^{\circ} \mathrm{C} \text { ). It was } \\
\text { reported that all the major physicochemical properties were better than earlier }\end{array}$ & \multirow[t]{2}{*}[28]{} \\
\hline & & $\begin{array}{l}\text { The outcomes revealed that the preheating of raw oil up to } 90^{\circ} \mathrm{C} \text { enhances the } \\
\text { engine efficiency and fuel consumption of fuel by the engine at higher loads in } \\
\text { comparison with mineral diesel }\end{array}$ & \\
\hline
\end{tabular}

these problems, researchers have done thorough work on the blending of biodiesel obtained from various vegetable or animal fat oil with mineral diesel [52]. However, only few researches are available on the production of dual biodiesel by mixing two different biodiesels with mineral diesel. This field has good scope for research to work on $[2,13]$. Dual biodiesel can decrease the emissions of harmful gases and improve engine performance [39, 60], which have been the focus of major research work worldwide. Only a few researchers have worked on the biodiesels prepared from Jatropha and Mahua blend with mineral diesel $[2,42]$, even though the properties of both Jatropha and Mahua oil biodiesel could be used to prepare dual biodiesel with improved physicochemical properties. There are many articles available on the investigations of emissions properties and engine performance parameters of individual Jatropha and Mahua oil biodiesel blends with mineral diesel, but the exploration of the possibilities of a dual blend of Mahua and Jatropha biodiesels with diesel fuel is still wide open.

It is evident from the literature survey that researchers have been trying to obtain a substitute fuel to the presently used mineral diesel by preparing blended dual biodiesel with enhanced engine combustion and emission properties [1, 31, 45, 56]. Further, a few researchers have also tried in the recent past to varying the engine combustion parameters with different variations of blended dual biodiesel to improve engine output and exhaust emissions $[7,22,42,55]$. Their studies have revealed that the blending of two different biodiesels has a significant impact on the combustion and emissions properties of fuel [46]. Also, some researchers have lately successfully improved the oxidation stability of biodiesel by preparing dual biofuel with the blending of two different biodiesels [2]. The direct impact of two different biodiesels blending on the engine output parameters and emission characteristics of the dual biofuel is still limited as very few works of literature are available on the same.

Therefore, in the present work, we aim to evaluate the parameters of engine output (such as In-cylinder peak pressure, mechanical efficiency, brake power, brake-specific fuel consumption, and exhaust gas temperature) and emissions gases (carbon dioxide, carbon monoxide, and hydrocarbons) using VCR engine of Mahua and Jatropha Biodiesel and mineral diesel blend. The various compression ratios (CR) used in current research work were 13.5:1, 14.5:1, 15.5:1, and $16.5: 1$ at 50\% loading condition.

\section{Materials and methods}

\subsection{Preparation of various sample blends for dual biodiesel}

The individual biodiesel of Jatropha and Mahua oil was prepared using a two-step trans-esterification process. The trans-esterification reaction was carried out at a temperature of $65^{\circ} \mathrm{C}( \pm 1)$ using a water bath, and the reaction time was $30 \mathrm{~min}$. During the reaction, the temperature of the water bath was constantly maintained at $65{ }^{\circ} \mathrm{C}( \pm 1)$. After every $5 \mathrm{~min}$, the solution was stirred using a glass rod. In the end, the obtained solution was drained into a separating funnel and it was kept aside for the next $24 \mathrm{~h}$. Finally, the biodiesel was separated, and the average yield of biodiesel was observed to be $93 \%$ for Jatropha and $89 \%$ for Mahua oil, respectively. Figure 1 illustrates the prepared sample of biodiesel using the trans-esterification process. Table 2 shows the comparison of physicochemical properties of biodiesels used in the present work.

The various physicochemical properties (density, acid value, kinematic viscosity, iodine value, flash point, fire point, cloud point, and pour point) of these synthesized 


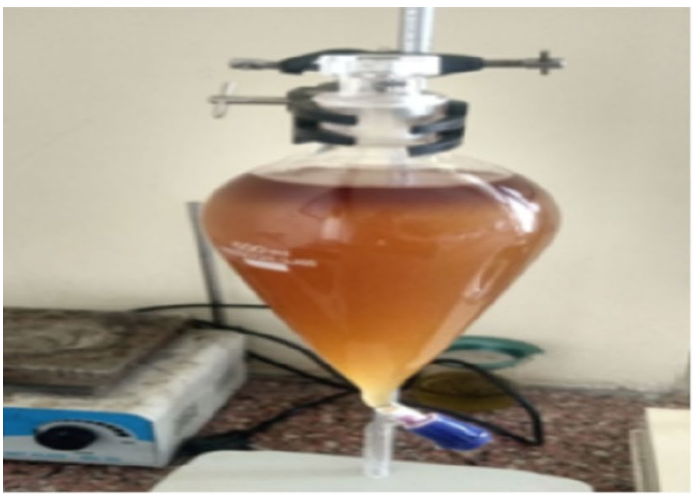

(a) Biodiesel sample with glycerin

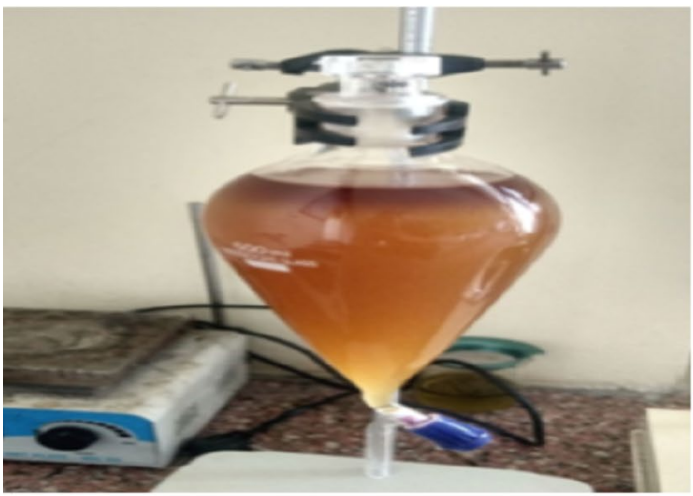

(c) Water washing to obtain pure biodiesel

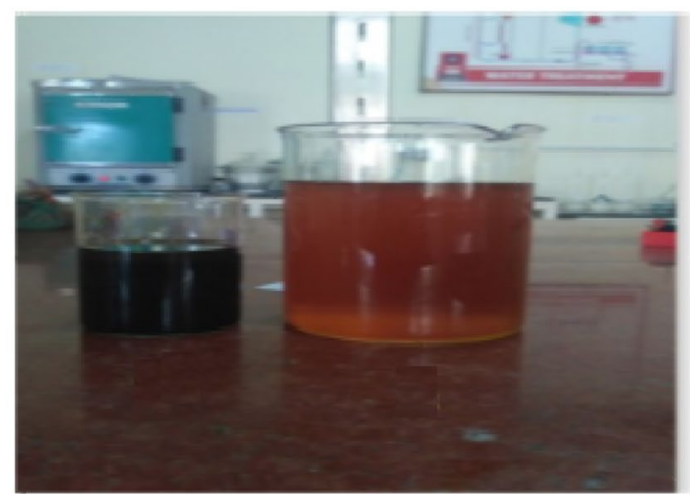

(b) Biodiesel sample after separation of glycerin

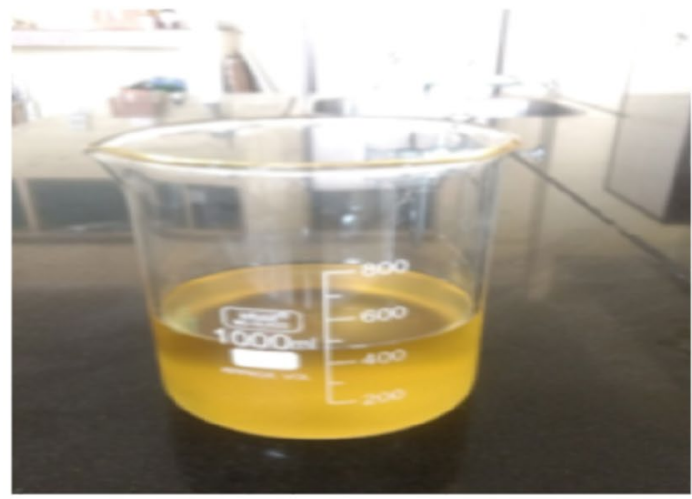

(d) Pure biodiesel obtained after water washing

Fig. 1 a Biodiesel sample with glycerin. b Biodiesel sample after separation of glycerin. c Water washing to obtain pure biodiesel. d Pure biodiesel obtained after water washing

Table 2 Comparison of physicochemical properties of biodiesels [47]

\begin{tabular}{|c|c|c|c|c|c|c|}
\hline Properties & Units & Mahua oil & Jatropha oil & $\begin{array}{l}\text { Mahua oil } \\
\text { biodiesel }\end{array}$ & $\begin{array}{l}\text { Jatropha } \\
\text { oil bio- } \\
\text { diesel }\end{array}$ & Mineral diesel \\
\hline Acid value & $\mathrm{mg} \mathrm{KOH} / \mathrm{g}$ & 35.00 & 28.00 & 0.45 & 0.40 & 0.21 \\
\hline lodine value & $\mathrm{g}$ of $\mathrm{I}_{2} / 100 \mathrm{~g}$ & 70.00 & 108.67 & 60.33 & 98.67 & - \\
\hline Density & $\mathrm{kg} / \mathrm{m}^{3} @ 20^{\circ} \mathrm{C}$ & 918.33 & 950.33 & 864.33 & 875.10 & 830.00 \\
\hline Kinematic viscosity & cSt @ 40ㄷ & 24.66 & 38.33 & 4.07 & 4.39 & 2.60 \\
\hline Flash point & ${ }^{\circ} \mathrm{C}$ & 234.67 & 224.67 & 174.67 & 140.33 & 65.00 \\
\hline Fire point & ${ }^{\circ} \mathrm{C}$ & 245.67 & 234.67 & 185.33 & 152.33 & 78.00 \\
\hline Cloud point & ${ }^{\circ} \mathrm{C}$ & 12 & 6.33 & 5.33 & -0.67 & -3.00 \\
\hline Pour point & ${ }^{\circ} \mathrm{C}$ & 8 & 2.67 & 2.00 & -6.33 & -8.00 \\
\hline
\end{tabular}

biodiesels had been evaluated previously. The physicochemical properties were found to be within the limits of different standards of biodiesels (National and International). Further, from these biodiesels, various dual biodiesel sample blends were prepared by mixing them in various proportions with mineral diesel. The compositions of various dual biodiesel sample blends are summarized below:
B10: JBD 05\%, \& MBD 05\% with mineral diesel 90\%, by vol.

B20: JBD 10\%, \& MBD 10\% with mineral diesel $80 \%$, by vol.

B30: JBD 15\%, \& MBD 15\% with mineral diesel 70\%, by vol.

B40: JBD $20 \%$, \& MBD $20 \%$ with mineral diesel $60 \%$, by vol. 
Table 3 represents the comparison of physicochemical properties of biodiesel blends with mineral diesel used in the present work.

The physical and chemical properties of these sample blends (dual biodiesel) were examined as per the standards of biodiesels given by various agencies (National and International) and were found to be within limits.

The above-mentioned dual biodiesel sample blends were tested for their emission characteristics and engine performance parameters using the VCR engine at varying $\mathrm{CR}$ during the current research work.

\subsection{Engine description}

The research work was conducted on a VCR four-stroke single-cylinder diesel engine connected with an eddy current dynamometer. The setup was used to determine the results of varying $C R$ in the engine cylinder to the operational and exhaust emissions. The performance parameters were evaluated for the engine (such as mechanical efficiency, brake power, brake-specific fuel consumption, In-cylinder peak pressure, and exhaust gas temperature).

The computerized data acquisition system coupled with the VCR engine is used to perform the experiments and to collect and store data. The experimentation setup used for the study is presented in Figs. 2 and 3. Further, Table 4 presents the various specifications of the VCR engine used for the research work.

\subsection{Gas analyzer description}

Five gas analyzer AVG-500 (AIRVISOR) model was connected to a VCR engine to analyze the emissions. It was provided with an exhaust gas inlet which was put in

Table 3 The comparison of properties (physical and chemical) of various dual biodiesel blend samples with the mineral diesel [47]

\begin{tabular}{|c|c|c|c|c|c|c|}
\hline $\begin{array}{l}\text { Physical and chemical } \\
\text { properties }\end{array}$ & Units & $\begin{array}{l}\text { Dual biodiesel } \\
\text { sample blend } \mathrm{B} 10\end{array}$ & $\begin{array}{l}\text { Dual biodiesel } \\
\text { sample blend B20 }\end{array}$ & $\begin{array}{l}\text { Dual biodiesel } \\
\text { sample blend B30 }\end{array}$ & $\begin{array}{l}\text { Dual biodiesel } \\
\text { sample blend B40 }\end{array}$ & Mineral diesel \\
\hline Acid value(max) & $\mathrm{mg} \mathrm{KOH} / \mathrm{g}$ & 0.21 & 0.24 & 0.33 & 0.40 & 0.20 \\
\hline lodine value & $\mathrm{g}$ of $\mathrm{I}_{2} / 100 \mathrm{~g}$ & 89.00 & 90.33 & 91.67 & 94.00 & - \\
\hline Density & $\mathrm{kg} / \mathrm{m}^{3} @ 20^{\circ} \mathrm{C}$ & 839.00 & 850.67 & 865.00 & 870.67 & 830.00 \\
\hline Kinematic viscosity & cSt @ $40{ }^{\circ} \mathrm{C}$ & 2.68 & 3.13 & 3.67 & 4.09 & 2.60 \\
\hline Flash point & ${ }^{\circ} \mathrm{C}$ & 75.00 & 88.00 & 100 & 114.33 & 65.00 \\
\hline Fire point & ${ }^{\circ} \mathrm{C}$ & 86.00 & 98.33 & 112.00 & 124.67 & 78.00 \\
\hline Cloud point & ${ }^{\circ} \mathrm{C}$ & -2.00 & -1.00 & 3 & 5.33 & -3 \\
\hline Pour point & ${ }^{\circ} \mathrm{C}$ & -5.00 & -3.00 & -1.67 & 0.33 & -8.00 \\
\hline
\end{tabular}

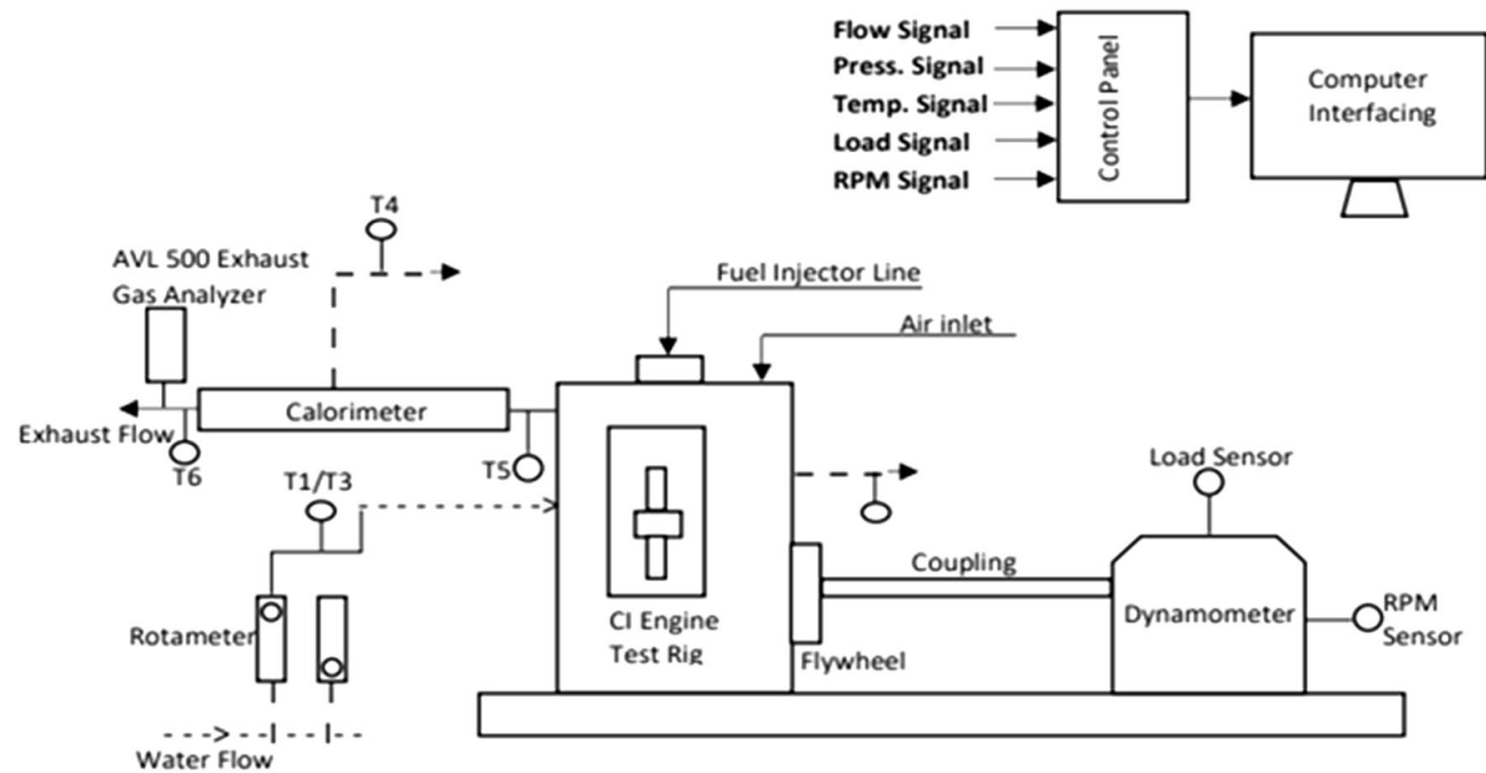

Fig. 2 The schematic diagram of the experimental setup (VCR engine) used 


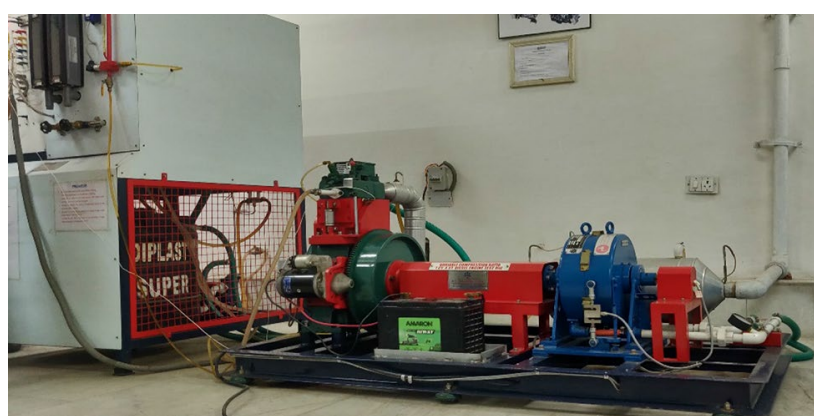

Fig. 3 The photographic view of the experimental setup (VCR engine) used

Table 4 Details of specifications: engine used and instruments

\begin{tabular}{ll}
\hline Parameter & Specifications \\
\hline Engine make & Kirloskar \\
Type & Kirloskar, inline, vertical, water cooling \\
Cylinders & Single \\
Strokes & Four \\
Power rating & $5.2 \mathrm{~kW}$ \\
Rated rpm & 1500 \\
Compression ratio & $13.5: 1 ; 14.5: 1 ; 15.5: 1$ and 16.5:1 \\
Pressure sensor & Piezo-electric sensor \\
Injection timing & $23^{\circ}$ BTDC \\
Type of ignition & Compression-ignition \\
Loading method & Eddy current dynamometer \\
Starting method & Self-start \\
Fuel tanks & One \\
Software used & National Instruments Software \\
\hline
\end{tabular}

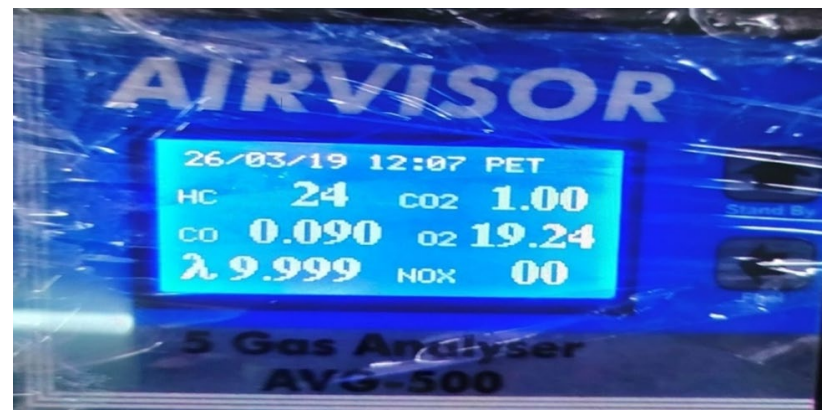

Fig. 4 Photographic view of the gas analyzer AVG-500

the exhaust gas pipe. Hydrocarbons, carbon monoxide, and carbon dioxide were analyzed during this work. The photograph of the exhaust gas analyzer is given in Fig. 4.
Table 5 The summary of accuracy ranges for the measurements taken on VCR engine

\begin{tabular}{lll}
\hline Instrument-Kirloskar VCR engine & $\begin{array}{l}\text { Accuracy for } \\
\text { measurements }\end{array}$ & Uncertainty (\%) \\
\hline Pressure transducer & $\pm 0.5 \mathrm{bar}$ & \pm 0.2 \\
Speed sensor & $\pm 2 \mathrm{rpm}$ & \pm 0.2 \\
Load sensor & $\pm 0.5 \mathrm{~N}$ & \pm 0.25 \\
Temperature sensor & $\pm 1^{\circ} \mathrm{C}$ & \pm 1.2 \\
Power & $\pm 1 \%$ & \pm 0.1 \\
Specific fuel consumption & $\pm 2 \%$ & \pm 0.2 \\
\hline
\end{tabular}

Table 6 The summary of accuracy ranges for the measurements taken on AVG exhaust gas analyzer

\begin{tabular}{lll}
\hline $\begin{array}{l}\text { Instrument-AVG exhaust } \\
\text { gas analyzer }\end{array}$ & $\begin{array}{l}\text { Accuracy for meas- } \\
\text { urements }\end{array}$ & Uncertainty (\%) \\
\hline $\mathrm{HC}$ & $\pm 10 \mathrm{ppm}$ & \pm 0.2 \\
$\mathrm{CO}$ & $\pm 0.02 \% \mathrm{vol}$ & \pm 0.2 \\
$\mathrm{CO}_{2}$ & $\pm 0.5 \% \mathrm{vol}$ & \pm 0.15 \\
$\mathrm{NOx}$ & $\pm 15 \mathrm{ppm}$ & \pm 0.1 \\
\hline
\end{tabular}

\subsection{Experimental methodology}

To start and run the engine, ignition self-start switch was used, and initially, it was fueled with mineral diesel. When the operating temperature of the engine is reached, a 50\% load is applied to the engine. The warming phase ends when the cooling water temperature shows a stabilized reading of $60{ }^{\circ} \mathrm{C}$. The engine was tested at a fixed speed of $1500 \mathrm{rpm}$. During experiments, the readings were measured and recorded digitally in the computer system. The readings for combustion and emission parameters with respect to different $C R$ were evaluated for mineral diesel and dual biodiesel sample blends.

\subsection{Error and uncertainty analysis}

Error and uncertainties in the conduct of experimentation may arise due to many factors such as environmental conditions, the selection, and calibration of instruments and equipment used for research [21]. The accuracy of the experiments performed requires the analysis of uncertainties to be done. The analysis is done as explained by Dubey and Gupta [21] using the formulation given by authors the uncertainty for whole experimentation was calculated and found to be $\pm 0.58 \%$. The uncertainty ranges for different parameters of VCR engine and exhaust gas analyzer are shown in Tables 5 and 6. 


\subsection{Statistical regression analysis}

The MS Excel Software was used to perform all the statistical regression analysis and to develop a mathematical model. This model is used to develop the linear equations for fuel combustion characteristics and exhaust emission properties of different dual biodiesel sample blends with the changing parameters such as varying compression ratio and the blend percentage of biodiesel with mineral diesel. The developed linear equations along with the coefficient of regression $\left(R^{2}\right)$ can be effectively used for statistical analysis and to estimate the parameters at any given compression ratio and percentage of blending for the change in properties for the sample blends used. Further, some other researchers have also tried to develop models on similar grounds either for biodiesel-diesel blends or biodiesel-biodiesel blends $[9,59]$

\section{Results and discussion}

\subsection{Characteristics of engine operation}

The current research work evaluated the engine's operational parameters and characteristics of exhaust emissions using various sample blends of dual biodiesel. These sample blends of dual biodiesel were prepared earlier by the mixing of Jatropha and Mahua oil biodiesel in equal proportions of volume (1:1) with mineral diesel. The various sample blends were obtained on the percentage by volume basis B10, B20, B30, and B40 (B10 is a blend of $5 \%$ each biodiesel with $90 \%$ mineral diesel and similarly for all other sample blends). The dual biodiesel sample blends were tested for engine operational performance characteristics (mechanical efficiency, brake specific fuel consumption, brake power, and tailpipe gases temperature) and emission characteristics (carbon dioxide, carbon monoxide, and hydrocarbons) at different compression ratios $(13.5: 1,14.5: 1,15.5: 1,16.5: 1)$ by using the VCR engine. The results for various parameters are summarized in Table 8 .

\subsection{Brake power (BP)}

$\mathrm{BP}$ is the power generated by the engine at the output. It defines the engine's capacity to do work with the fuel used. The brake power with the variation in CR for different tested dual biodiesel sample blends is presented in Fig. 5 . The results revealed that the brake power escalated with the increase in CR. At a lower compression ratio of 13.5:1, it was found to be highest ( $0.994 \mathrm{~kW})$ for blend B40 and at a higher CR of 16.5:1, it also came out to be highest $(1.283 \mathrm{~kW})$ for the same blend sample. The performance of B40 was better than other fuel blends and it was found

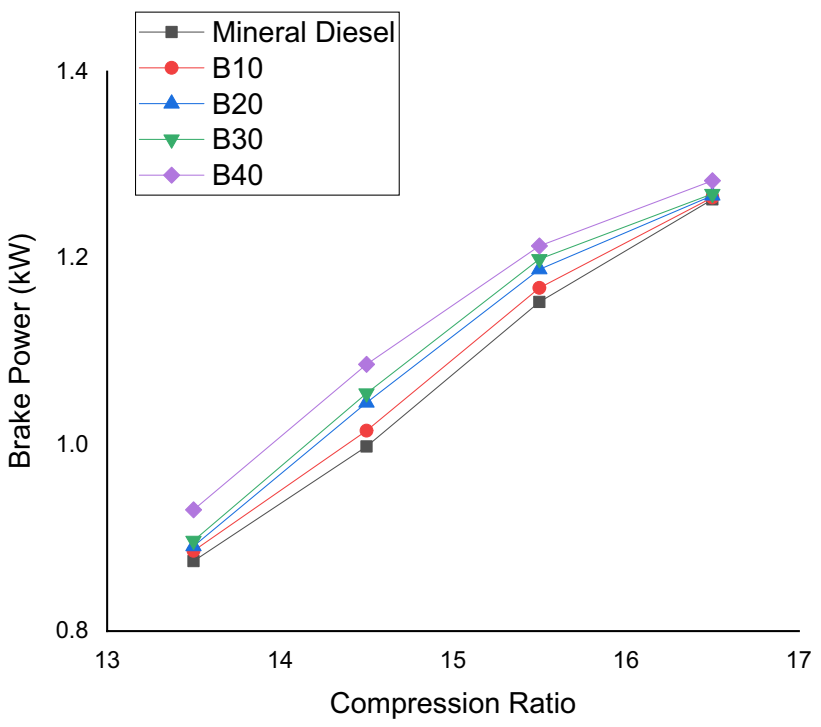

Fig. 5 Variation of BP of dual biodiesel sample blends at different compression ratios

to be greater by $1.58 \%$ than mineral diesel $(1.263 \mathrm{~kW})$ at a compression ratio of 16.5:1. It is worthwhile to note that the brake power also surged as the CR was increased at fixed loading. The other blend samples also had better brake power as compared to mineral diesel at different $C R$. The increase in brake power was seen to be linear to the compression ratio. Nagaraja et al. [34] also reported an increase in brake power for percentage increase in biodiesel blend while working on palm biodiesel. The reason for the same could be an improvement in the mixing of air-fuel ratio, better atomization-spray characteristics, and proper combustion of fuel due to preheating. Also, another reason can be the density of the B40 blend, which was more in comparison with mineral diesel. As the denser fuel-air mixture goes into the engine cylinder, the engine brake power is improved $[33,35]$.

\subsection{Mechanical efficiency (ME)}

ME indicates overall engine performance with the calorific value given by the combustion of fuel. The trends of mechanical efficiency for various dual biodiesel sample blends at variable compression ratios are shown in Fig. 6 . It was noted that the overall ME of the sample blends (dual biodiesel) increased as the $C R$ was increased, that means the ME of the dual biodiesel samples varied directly with the variation of CR. ME was found 19.66, 21.28, 21.92, and $23.97 \%$ for B10, B20, B30, and B40 at CR of 13.5:1, respectively. For higher $C R$ of $16.5: 1$, it came out to be $30.1,31.64,32.55$, and $33.48 \%$ for B10, B20, B30, and B40, respectively. The mechanical efficiency was found to be $18.95 \%$ and $29.78 \%$ for mineral diesel at $13.5: 1$ and 16.5:1 


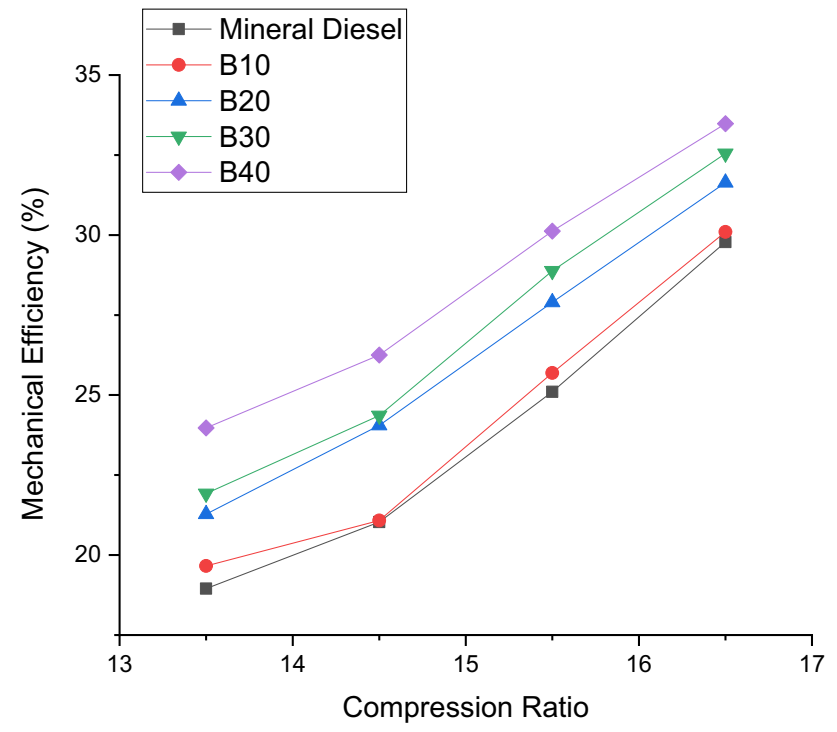

Fig. 6 Variation of ME of dual biodiesel sample blends at different compression ratios

$\mathrm{CR}$, respectively. The blend sample $\mathrm{B} 40$ had the maximum ME for CR 16.5:1 which was $33.48 \%$. Further, it was $12.42 \%$ greater than conventionally used diesel fuel.

Agarwal and Rajamanoharan [4] also reported an increase in engine $\mathrm{ME}$ with the rise in blend percentage at a higher CR in the case of Karanja biodiesel blends. This could be due to the better lubrication properties of blended dual biodiesel samples owing to the presence of methyl esters in the fuel samples used for combustion [37].

\subsection{In-cylinder peak pressure (In-CPP)}

The peak pressure produced in the combustion chamber inside the engine cylinder just after the TDC is known as the In-cylinder peak pressure. The trends of In-cylinder peak pressure were found to be increasing with an increase in CR. However, it was revealed to be decreasing with the higher blend percentage of biodiesels in mineral diesel. The trends for various sample blends tested at different CR are presented in Fig. 7.

At lower CR, mineral diesel (D100) had a lower value of In-CPP (1.23 bar) whereas it surged with the increase in CR and was found to be highest ( $2.14 \mathrm{bar}$ ) for mineral diesel at 16.5:1 CR. The results revealed that the dual biodiesel sample blends had a lower value of In-CPP. At CR of 13.5:1, it was found to be low and similar to that of diesel for samples $B 10, B 20$, and $B 30(1.21,1.2$, and 1.2 bar, respectively), and B40 had an even lower In-CPP of 1.19 bar. However, even though In-CPP of biodiesel samples surged for higher $C R$, it was still found to be lower in comparison with mineral diesel. The value of In-CPP for mineral diesel (D100) came out to be 2.14 bar, for B30 it was 1.84 bar, and for

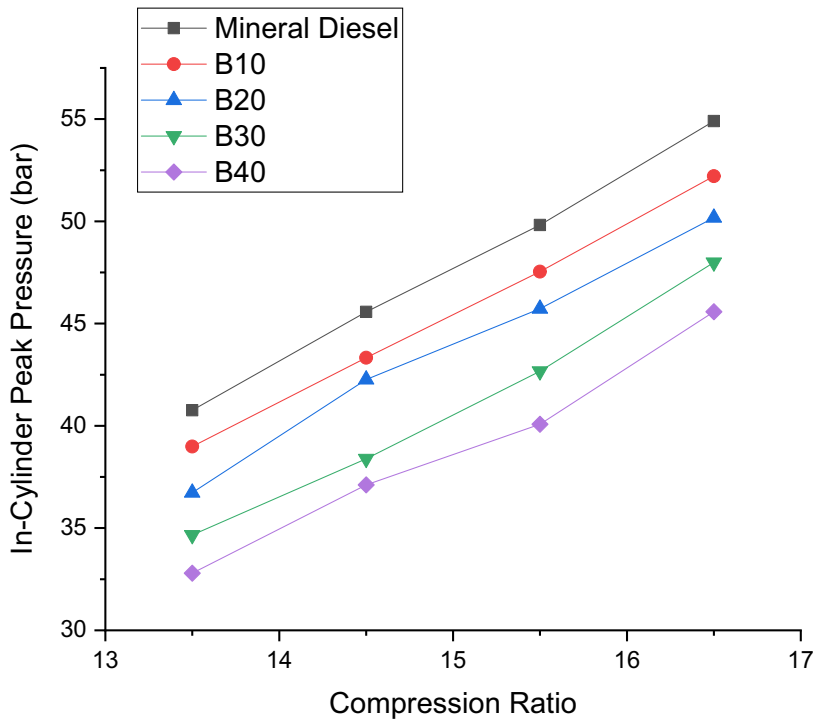

Fig. 7 Variation of In-CPP of dual biodiesel sample blends at different CR

B40 1.78 bar at the maximum CR (16.5:1). On average, it was evident that among all the tested samples of dual biodiesel, the B40 had the lowest value which was $16.82 \%$ lower than mineral diesel. The reason for the same could be the lower calorific values of biodiesel than mineral diesel. Muralidharan and Vasudevan reported a similar decrease in In-CPP during their research on biodiesel produced from the waste cooking oil and diesel blends. [33].

\subsection{Brake-specific fuel consumption (BSFC)}

BSFC indicates the fuel efficiency of an IC engine. It primarily compares the consumption of fuel to the power produced by the engine. BSFC reduced progressively with the increase in CR from 13.5 to 16.5 for all tested dual biodiesel sample blends and a similar trend was also observed for mineral diesel. At CR of 13.5:1, the BSFC was found to be 1.69 (B10), 1.71 (B20), 1.72 (B30), and 1.78 (B40) kg/kW-s. At CR of 16.5:1, it was lower at 1.35 (B10), 1.41 (B20), 1.48 (B30), and 1.59 (B40). It was evident that as the blend percentage increased, the BSFC of the fuel also got higher. The dual biodiesel blend B40 had the highest BFSC at CR of $16.5: 1$ which was $20.45 \%$ greater as compared to mineral diesel.

This possible reason for this could be because of the lower heat content value of B40 due to the higher methyl ester content present in the dual biodiesel sample blends when compared with the mineral diesel. Mathew and Anand reported similar results during their work on biodiesel prepared from fresh and waste cooking oil [32]. The variation of BSFC of dual biodiesel sample blends at different CRs is presented in Fig. 8. 


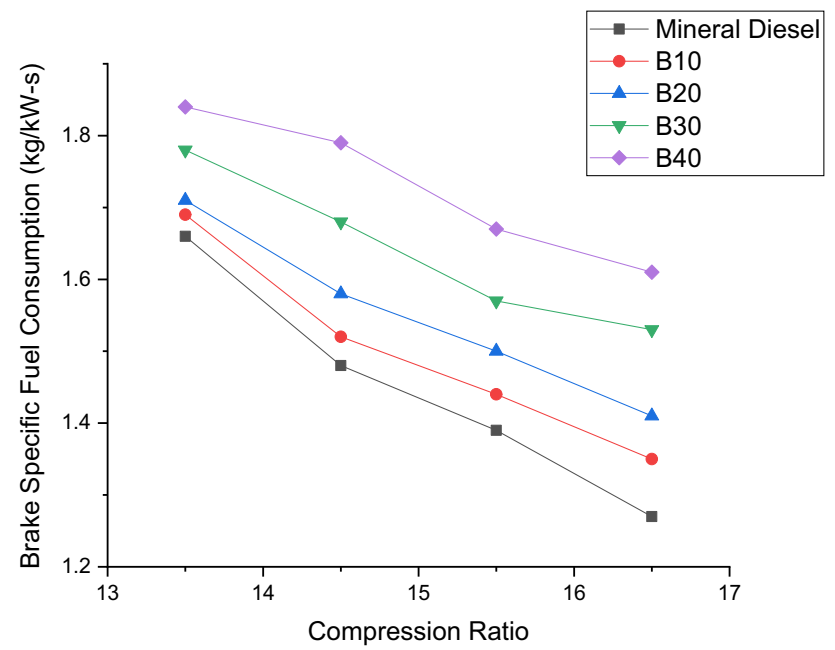

Fig. 8 Variation of BSFC of dual biodiesel sample blends at different compression ratios

\subsection{Exhaust gas temperature (EGT)}

The results of EGT for different dual biodiesel sample blends are shown in Fig. 9. The results clearly show that the temperature of exhaust gases was lower for all the sample blends when compared to EGT of mineral diesel when the CR was raised from 13.5:1 to 16.5:1. The B10 blend, however, had nearly the same values of EGT as that of mineral diesel (D100) which was recorded to be $185.7^{\circ} \mathrm{C}$ at the lowest $C R$ and $279.4^{\circ} \mathrm{C}$ at the higher CR. The B40 blend had the lowest EGT among all tested sample blends. It was found to be $132.1{ }^{\circ} \mathrm{C}$ and $220.7{ }^{\circ} \mathrm{C}$ for the lowest and highest

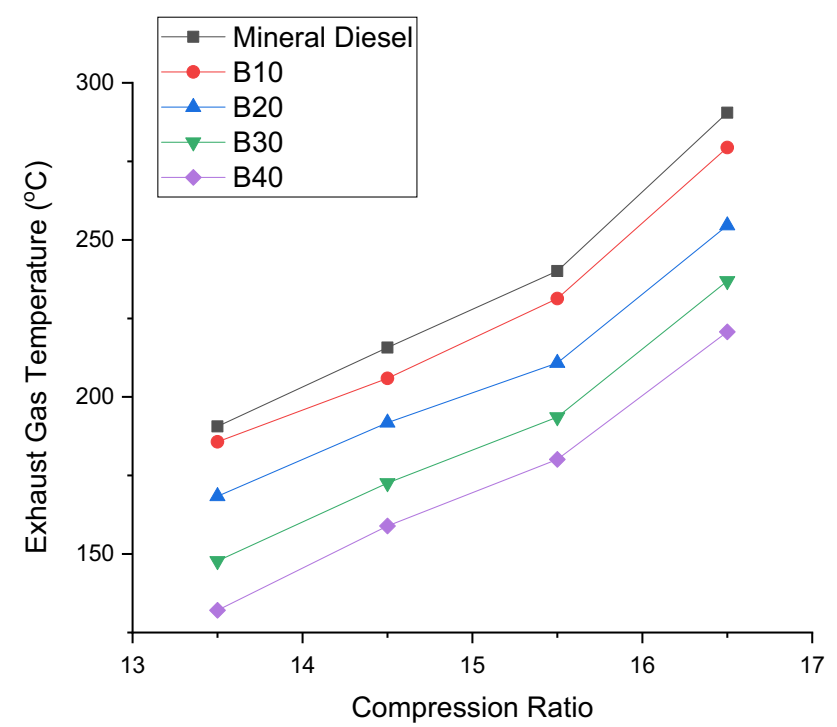

Fig. 9 Variation of EGT of dual biodiesel sample blends at different compression ratios tested compression ratios. For the highest sample blend B40, the EGT was $11.1-69.8{ }^{\circ} \mathrm{C}$ lower than mineral diesel for different CR (13.5:1-16.5:1). The lower EGT recorded for dual biodiesel sample blends could be due to the lower heat value of the biodiesel in comparison with the mineral diesel. The present study as discussed above also showed similar results. The lower amount of exhaust losses could also be attributed to higher brake power and mechanical efficiency [11].

\subsection{Emission analysis}

The emission analysis was done with the help of a 5-gas analyzer to evaluate the exhaust emissions of carbon dioxide $\left(\mathrm{CO}_{2}\right)$, hydrocarbons $(\mathrm{HC})$, and carbon monoxide (CO) for all dual biodiesel samples. The Indian National standards followed for the analysis of emission are given in Table 7.

\subsection{Carbon monoxide (CO)}

The $\mathrm{CO}$ emissions of an engine largely depend upon the quality of fuel used, amount of oxygen present in the fuel, ratio of the $A / F$ mixture, turbulence, and temperature inside the engine cylinder. The trend of $\mathrm{CO}$ exhaust for dual biodiesel sample blends at various $C R$ is presented in Fig. 10. The results revealed that the $\mathrm{CO}$ emissions were found to be $0.07,0.06$, and $0.06 \%$ at CR of $13.5: 1$ for sample blends B10, B20, and B30, respectively. Further, with the increase in $C R$, the $C O$ emissions were found to be even lower. It was $0.06,0.05$, and $0.04 \%$ for sample blend $B 10$, $B 20$, and B30, respectively. However, the sample blend B40 had the lowest value for $\mathrm{CO}$ gas emission with the values of $0.05 \%$ at a lower CR of $13.5: 1$ and $0.04 \%$ at a higher CR of 16.5:1. This percentage was even lower than that of mineral diesel. The $\mathrm{CO}$ emission of other samples was also less than mineral diesel at various CR's. In comparison with mineral diesel, B40 blend emitted 33.33\% lesser CO gases (Table 8).

The reason behind less emission of $\mathrm{CO}$ gas by all dual biodiesel samples is the preheating process that improves the fuel atomization and sprays characteristics [21]. These trends revealed the quality of the combustion of dual biodiesel due to more quantity of oxygen present in these

Table 7 The summary of Indian National standards used for the analysis of emission

\begin{tabular}{ll}
\hline Elements & Standards for measurements \\
\hline $\mathrm{HC}$ & - \\
$\mathrm{CO}$ & IS 11293: 1992 \\
$\mathrm{CO}_{2}$ & IS 13270: 1992 (1999 reaffirmed) \\
\hline
\end{tabular}




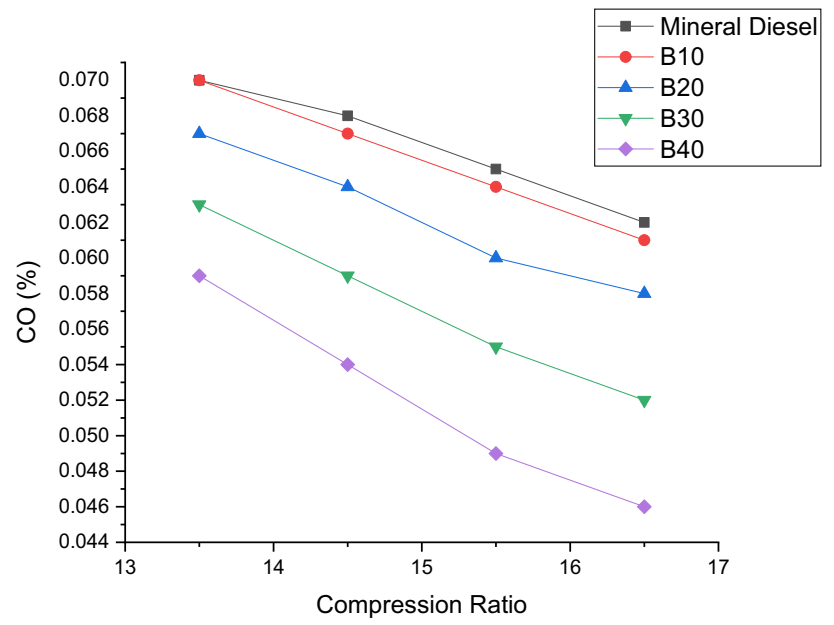

Fig. 10 Variation of carbon monoxide emissions of dual biodiesel sample blends at different compression ratios

samples. Further, results showed that as the blend percentage rises, the emission of $\mathrm{CO}$ decreases. The increase in the compression ratio reduced the carbon monoxide output due to the higher amount of temperature produced during the air-fuel combustion [19]. The result analysis clearly revealed that a greater blend percentage of biodiesel results in lower emissions of toxic CO. Dubey and Gupta reported lower $\mathrm{CO}$ emissions during the analysis of Jatropha and turpentine biodiesel at a constant speed using a diesel single-cylinder engine [21]. Chauhan et al. also reported similar results in the case of diesel and Jatropha biodiesel blends in a diesel single-cylinder engine at constant load. A similar decrease in carbon monoxide emission was also reported by other researchers with the increase in $\mathrm{CR}$ and blend percentage during their research work [15].

\subsection{Carbon dioxide $\left(\mathrm{CO}_{2}\right)$}

The trend of $\mathrm{CO}_{2}$ emission for dual biodiesel sample blends at different $\mathrm{CRs}$ is presented in Fig. 11. All sample blends emit higher $\mathrm{CO}_{2}$ as compared to mineral diesel with increasing CR. The emissions of carbon dioxide were found to be lower for all dual biodiesel sample blends at CR of 13.5:1 (1.09, 1.43, 1.61, and 1.8\% for sample blends B10, B20, B30, and B40, respectively). However, the emissions values increased with the increase in compression ratio. At a higher $C R$ of 16.5:1, it was recorded to be 1.7, 1.8, 2.0, and $2.1 \%$ for sample blend $\mathrm{B} 10, \mathrm{~B} 20, \mathrm{~B} 30$, and $\mathrm{B} 40$, respectively. The $\mathrm{CO}_{2}$ emissions were recorded lowest for mineral diesel. At a lower CR of $13.5: 1$, it was recorded to be $0.98 \%$, whereas at a higher CR (16.5:1) it was observed to be $1.2 \%$. It was observed that $\mathrm{CO}_{2}$ emission was $42.85 \%$ lower when compared with the highest percentage blend of biodiesel.
The higher value of $\mathrm{CO}_{2}$ emissions could be due to enhanced air-fuel combustion inside the cylinder due to the greater oxygen content present in the dual biodiesel blends. Higher $\mathrm{CO}_{2}$ emission as compared to $\mathrm{CO}$ is the indication of better fuel combustion in an engine cylinder. The higher quantity of $\mathrm{CO}_{2}$ is although harmful to the environment, but less toxic than $\mathrm{CO}$ and also consumed by various plants for the photosynthesis process. Dubey and Gupta revealed greater $\mathrm{CO}_{2}$ in the exhaust for Jatropha and turpentine dual biodiesel sample blends tested at a fixed speed in the 4-stroke, 1-cylinder $\mathrm{Cl}$ engine [23]. Other researchers also reported similar results in case of other different biodiesel blends [21, 27].

\subsection{Hydrocarbons (HC)}

The trend of $\mathrm{HC}$ emission for different dual biodiesel sample blends at various $C R$ is shown in Fig. 12. All the dual biodiesel sample blends had lower HC emissions than mineral diesel at all CRs for fixed loading conditions. The $\mathrm{HC}$ emissions were recorded to be highest (44 ppm) for mineral diesel at the lowest CR of 13.5:1. However, with the rise in $\mathrm{CR}$, the $\mathrm{HC}$ emissions were reduced and were recorded to be $32 \mathrm{ppm}$ for mineral diesel. The dual biodiesel sample blends had lower HC emissions as compared to the mineral diesel. Further, $\mathrm{HC}$ emission was found to be the lowest for the highest sample blend percentage B40. The emissions of $\mathrm{HC}$ have recorded $28 \mathrm{ppm}$ at a lower $\mathrm{CR}$ (13.5:1), and it even lower down to $12 \mathrm{ppm}$ at a higher $C R$ (16.5:1) for dual biodiesel sample blends. Also, the other sample blends had lower $\mathrm{HC}$ emissions when compared with the mineral diesel at all CRs.

The increased value for $C R$ in the engine resulted in lowering the $\mathrm{HC}$ percentage in the exhaust for all tested dual biodiesel sample blends. The lowering of $\mathrm{HC}$ emissions could be attributed to the higher amount of temperature inside the engine cylinder with the increase in CR. $\mathrm{HC}$ emissions for $\mathrm{B} 10$ blend and mineral diesel were $31 \%$ and $32 \%$, respectively. Further, B20, B30, and B40 blends had $22 \%, 18 \%$, and $12 \% \mathrm{HC}$ emission, respectively, at CR of 16.5:1.

Chauhan et al. also analyzed Jatropha biodiesel blends on the $\mathrm{Cl}$ engine and reported a decrease in emissions of $\mathrm{HC}$ for biodiesel than mineral diesel [15]. Similar results of $\mathrm{HC}$ emission were also reported by other researchers in the case of other different biodiesel blends $[17,57]$.

Saravanan et al. [46] prepared a mixture of Mahua and Rapeseed oil biodiesel in the same proportions by volume and performed an experimental analysis. They observed that the performance of the B20 blend was very close to that of mineral diesel during testing. The brake thermal efficiency for sample blend B20 was noted $2.8 \%$ lower than that of mineral diesel. Also, 
Table 8 Summarizes the variation of engine performance and emission characteristics of all dual biodiesel samples at different compression ratios compared with mineral diesel

\begin{tabular}{|c|c|c|c|c|c|c|c|c|}
\hline $\begin{array}{l}\text { Compres- } \\
\text { sion ratio }\end{array}$ & Parameter & Units & B10 & B20 & B30 & B40 & B20 Blend [14] & Mineral diesel \\
\hline \multirow[t]{8}{*}{ 13.5:1 } & $\mathrm{BP}$ & $\mathrm{kW}$ & 0.886 & 0.891 & 0.897 & 0.994 & - & 0.875 \\
\hline & ME & $\%$ & 19.66 & 21.28 & 21.92 & 23.97 & - & 18.95 \\
\hline & In-CPP & bar & 1.21 & 1.2 & 1.2 & 1.19 & - & 1.23 \\
\hline & BSFC & $\mathrm{kg} / \mathrm{kW}-\mathrm{s}$ & 1.69 & 1.71 & 1.72 & 1.78 & - & 1.66 \\
\hline & EGT & ${ }^{\circ} \mathrm{C}$ & 185.7 & 144.1 & 148.2 & 132.1 & - & 190.6 \\
\hline & $\mathrm{CO}$ & $\%$ & 0.07 & 0.06 & 0.06 & 0.05 & 0.035 & 0.07 \\
\hline & $\mathrm{CO}_{2}$ & $\%$ & 1.09 & 1.43 & 1.61 & 1.73 & - & 0.98 \\
\hline & $\mathrm{HC}$ & PPM & 43 & 41 & 36 & 28 & - & 44 \\
\hline \multirow[t]{8}{*}{ 14.5:1 } & $\mathrm{BP}$ & kW & 0.998 & 1.12 & 1.185 & 1.189 & - & 1.165 \\
\hline & ME & $\%$ & 21.08 & 24.05 & 24.36 & 26.25 & - & 21.03 \\
\hline & In-CPP & bar & 1.54 & 1.55 & 1.52 & 1.52 & - & 1.65 \\
\hline & BSFC & $\mathrm{kg} / \mathrm{kW}-\mathrm{s}$ & 1.51 & 1.54 & 1.58 & 1.57 & $0.31(\mathrm{~kg} / \mathrm{kWh})$ & 1.48 \\
\hline & EGT & ${ }^{\circ} \mathrm{C}$ & 201.8 & 194.5 & 177.1 & 167.1 & 410 & 215.7 \\
\hline & $\mathrm{CO}$ & $\%$ & 0.07 & 0.06 & 0.05 & 0.05 & 0.038 & 0.07 \\
\hline & $\mathrm{CO}_{2}$ & $\%$ & 1.3 & 1.5 & 1.8 & 1.9 & 2.6 & 1.1 \\
\hline & $\mathrm{HC}$ & PPM & 40 & 33 & 27 & 23 & 14 & 40 \\
\hline \multirow[t]{8}{*}{ 15.5:1 } & $\mathrm{BP}$ & kW & 1.204 & 1.208 & 1.255 & 1.276 & - & 1.197 \\
\hline & ME & $\%$ & 25.69 & 27.9 & 28.88 & 30.12 & - & 25.1 \\
\hline & In-CPP & bar & 1.73 & 1.56 & 1.5 & 1.56 & - & 1.89 \\
\hline & BSFC & $\mathrm{kg} / \mathrm{kW}-\mathrm{s}$ & 1.44 & 1.5 & 1.53 & 1.58 & $0.33(\mathrm{~kg} / \mathrm{kWh})$ & 1.39 \\
\hline & EGT & ${ }^{\circ} \mathrm{C}$ & 225.3 & 201.8 & 193.6 & 180.1 & 395 & 240.1 \\
\hline & $\mathrm{CO}$ & $\%$ & 0.06 & 0.05 & 0.05 & 0.04 & 0.018 & 0.06 \\
\hline & $\mathrm{CO}_{2}$ & $\%$ & 1.6 & 1.7 & 1.9 & 2 & 2.5 & 1.1 \\
\hline & $\mathrm{HC}$ & PPM & 31 & 22 & 18 & 12 & 8 & 32 \\
\hline \multirow[t]{8}{*}{ 16.5:1 } & $\mathrm{BP}$ & kW & 1.265 & 1.267 & 1.269 & 1.283 & - & 1.263 \\
\hline & ME & $\%$ & 30.1 & 31.64 & 32.55 & 33.48 & - & 29.78 \\
\hline & In-CPP & bar & 1.99 & 1.86 & 1.84 & 1.78 & - & 2.14 \\
\hline & BSFC & $\mathrm{kg} / \mathrm{kW}-\mathrm{s}$ & 1.35 & 1.41 & 1.48 & 1.59 & $0.31(\mathrm{~kg} / \mathrm{kWh})$ & 1.32 \\
\hline & EGT & ${ }^{\circ} \mathrm{C}$ & 279.4 & 254.6 & 223.3 & 220.7 & 380 & 290.5 \\
\hline & $\mathrm{CO}$ & $\%$ & 0.06 & 0.05 & 0.04 & 0.04 & 0.010 & 0.06 \\
\hline & $\mathrm{CO}_{2}$ & $\%$ & 1.7 & 1.8 & 2 & 2.1 & 2.5 & 1.2 \\
\hline & $\mathrm{HC}$ & PPM & 31 & 22 & 18 & 12 & 7 & 32 \\
\hline
\end{tabular}

carbon monoxide, unburned hydrocarbons, and smoke outlets for emissions were found to be $20.7 \%, 8.6 \%$, and $7 \%$ lower as compared to diesel, whereas $\mathrm{NO}_{\mathrm{x}}$ emissions increased by $3.8 \%$ [46]. Srithar and Balasubramanian [55] have also prepared a fuel from the combination of two biodiesels blend with diesel and found two samples among them had properties almost similar to that of diesel fuel. The thermal efficiency of DPJ1 (DPJ1 = Diesel $90 \%+$ Pongamia Pinnata 5\% + Jatropha 5\%) and DPJ2 (DPJ2 = Diesel 80\% + Pongamia Pinnata 10\% + Jatropha $10 \%$ ) were closer to that of diesel, and their specific fuel consumption was almost equal to that of diesel. From the emissions analysis, the results of DPJ1 and DPJ2 were found to be similar to diesel. The authors recommended these blend fuels as fuel for stationary diesel engines used for agricultural purposes [55].

\subsection{Statistical regression analysis}

The variation in engine emission and performance characteristics of all the sample blends of dual biodiesel were compared graphically with the change in CR. The MS Excel software was used for statistical regression analysis to determine the linear equations, correlation coefficient or regression coefficient $\left(R^{2}\right)$, and regression equations. The regression coefficient $\left(R^{2}\right)$ depicted the trends of various combustion and emission properties with the change in CR for any particular blend. The outcomes showed that all the engine performance parameters were directly proportional to the $\mathrm{CR}$ except $\mathrm{CO}$ and $\mathrm{HC}$ emissions which were found to be inversely proportional to the CR.

The mathematical models developed revealed a high coefficient of regression or regression coefficient $\left(R^{2}\right)$ 


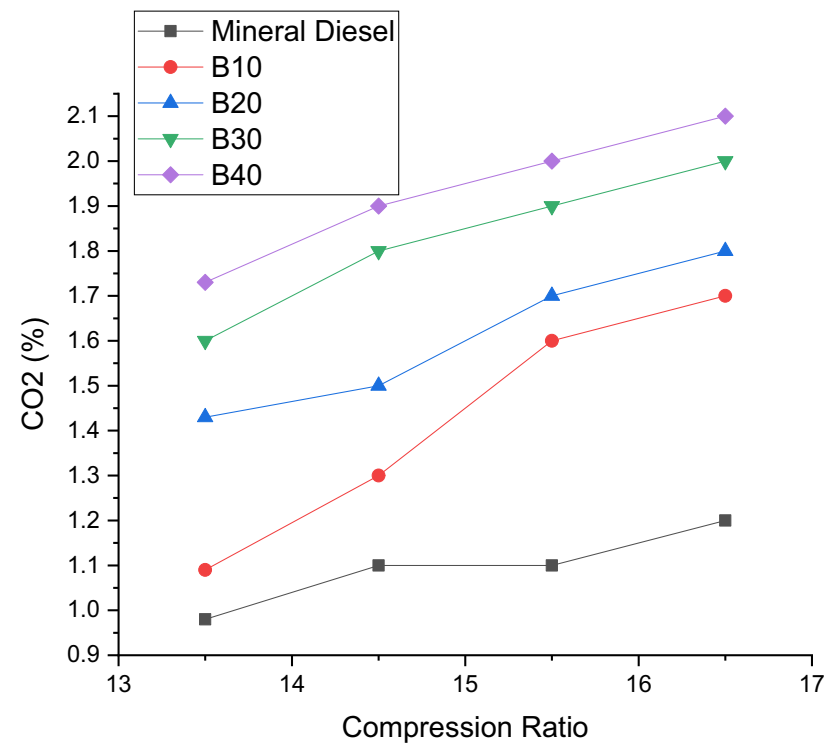

Fig. 11 Variation of carbon dioxide emissions of dual biodiesel sample blends at different compression ratios

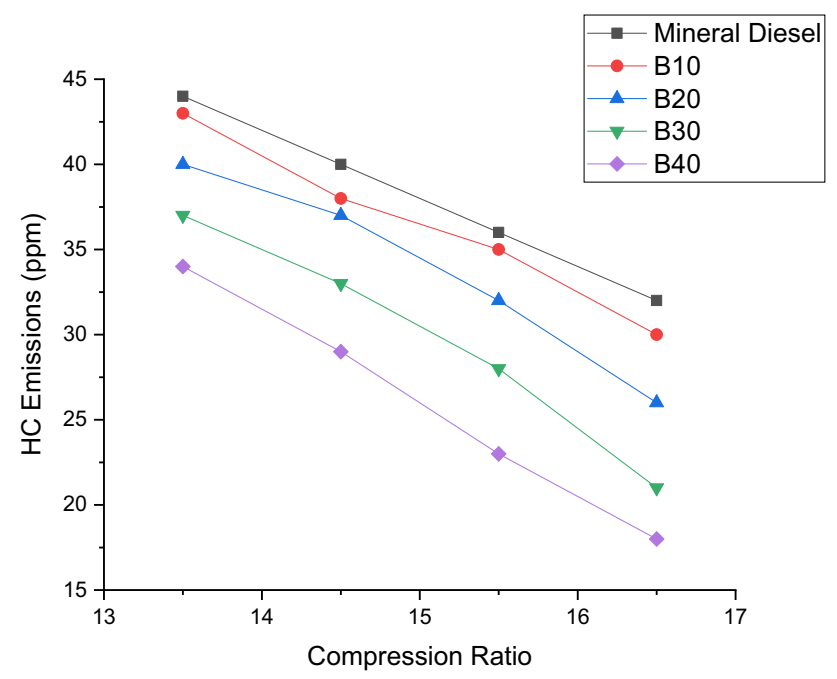

Fig. 12 Variation of hydrocarbon emissions of dual biodiesel sample blends at different compression ratios

between engine operational parameters and different compression ratios. The mathematical equation and regression coefficient for different dual biodiesel sample blends are summarized in Table 9.

\section{Conclusions}

In the current experimental work, dual biodiesel blends with diesel in different ratios were evaluated and compared with diesel for engine performance and emission characteristics on a VCR engine. The outcomes of the study revealed that the change in $C R$ leads to the varied engine outputs and emissions characteristics which are comparable with those of mineral diesel in a significant way. The conclusions drawn from the present experimental study are summarized below:

- All dual biodiesel samples tested had slightly greater brake power than mineral diesel. It varied from $0.15 \%$ to $1.58 \%$ more than mineral diesel (for sample blends $\mathrm{B} 10$ to $\mathrm{B} 40$ ) at the maximum value of compression ratio and under fixed loading conditions.

- The mechanical efficiency increased with an increase in $\mathrm{CR}$ at fixed loading conditions for both dual biodiesel samples and mineral diesel. Again, sample blends B10 to B40 had a little higher mechanical efficiency of $1.07 \%$ to $12.42 \%$ more than mineral diesel.

- The In-cylinder peak pressure of mineral diesel had a comparatively higher value than dual biodiesel samples and it lowered among the blend samples; B10 to B40 by 0.15 to 0.36 bar at the highest compression ratio tested.

- The increase in biodiesel blending percentage in the dual biodiesel samples resulted in higher brake specific fuel consumption, which was observed to be the highest for sample B40 (26.77\% more than mineral diesel) and least for sample B10 (2.27\%) when compared with mineral diesel.

- The exhaust gas temperature of all the dual biodiesel samples was found to be lower as compared to mineral diesel. B20 recorded $35.9^{\circ} \mathrm{C}, \mathrm{B} 30$, and $\mathrm{B} 40$ blend had $53.6^{\circ} \mathrm{C} \& 69.8^{\circ} \mathrm{C}$ while $\mathrm{B} 10$ had EGT $11.1^{\circ} \mathrm{C}$ lower than EGT of mineral diesel at 16.5:1 compression ratio.

- The emissions for carbon monoxide were recorded to be lower for all dual biodiesel samples than that of mineral diesel at maximum compression ratios. Further, the exhaust emissions of hydrocarbons were also reduced significantly for all dual biodiesel samples.

- The carbon dioxide gas emission was higher for all dual biodiesel samples in comparison with mineral diesel at all compression ratios.

- The fuel parameters tested on the engine in terms of combustion, efficiency, and emissions reported better results for dual biodiesel samples.

The current research study revealed that taking into consideration the overall engine combustion performance and emission parameters, the dual biodiesel B20 had superior fuel combustion and emission properties among all tested samples at a compression ratio of 16.5:1 and 50\% loading on the engine. From current findings, it may be concluded that the blended dual biodiesel showed comparatively better combustion and emissions properties at 
Table 9 The mathematical relation between different engine output parameters and compression ratio $(\mathrm{x})$ for various dual biodiesel sample blends and mineral diesel

\begin{tabular}{|c|c|c|c|c|}
\hline Compression ratio & Properties & Units & Mathematical relation & $\begin{array}{l}\text { Regression } \\
\text { coefficient }\left(R^{2}\right)\end{array}$ \\
\hline \multirow[t]{8}{*}{ Mineral diesel } & $\mathrm{BP}$ & kW & $0.119 x-0.669$ & 0.809 \\
\hline & ME & $\%$ & $3.656 x-31.12$ & 0.974 \\
\hline & In-CPP & Bar & $0.297 x-2.727$ & 0.979 \\
\hline & BSFC & $\mathrm{kg} / \mathrm{kW}-\mathrm{s}$ & $-0.141 x+3.552$ & 0.985 \\
\hline & EGT & ${ }^{\circ} \mathrm{C}$ & $32.41 x-251.9$ & 0.964 \\
\hline & $\mathrm{CO}$ & $\%$ & $-0.004 x+0.125$ & 0.8 \\
\hline & $\mathrm{CO}_{2}$ & $\%$ & $0.066 x+0.105$ & 0.896 \\
\hline & $\mathrm{HC}$ & PPM & $4 x+98$ & 1.0 \\
\hline \multirow[t]{8}{*}{ B10 } & $\mathrm{BP}$ & kW & $0.134 x-0.926$ & 0.962 \\
\hline & ME & $\%$ & $3.593 x-29.76$ & 0.958 \\
\hline & In-CPP & Bar & $0.253 x-2.177$ & 0.989 \\
\hline & BSFC & $\mathrm{kg} / \mathrm{kW}-\mathrm{s}$ & $-0.109 x+3.132$ & 0.953 \\
\hline & EGT & ${ }^{\circ} \mathrm{C}$ & $30.46 x-233.8$ & 0.922 \\
\hline & $\mathrm{CO}$ & $\%$ & $-0.004 x+0.125$ & 0.8 \\
\hline & $\mathrm{CO}_{2}$ & $\%$ & $0.273 x-2.722$ & 0.938 \\
\hline & $\mathrm{HC}$ & PPM & $-4.1 x+98.75$ & 0.991 \\
\hline \multirow[t]{8}{*}{ B20 } & $\mathrm{BP}$ & $\mathrm{kW}$ & $0.121 x-0.702$ & 0.904 \\
\hline & ME & $\%$ & $3.493 x-26.17$ & 0.995 \\
\hline & In-CPP & Bar & $0.199 x-1.442$ & 0.906 \\
\hline & BSFC & $\mathrm{kg} / \mathrm{kW}-\mathrm{s}$ & $-0.094 x+2.95$ & 0.932 \\
\hline & EGT & ${ }^{\circ} \mathrm{C}$ & $33.88 x-309.4$ & 0.935 \\
\hline & $\mathrm{CO}$ & $\%$ & $-0.004 x+0.115$ & 0.80 \\
\hline & $\mathrm{CO}_{2}$ & $\%$ & $0.317 x-3.302$ & 0.841 \\
\hline & $\mathrm{HC}$ & PPM & $-6.2 x+124$ & 0.990 \\
\hline \multirow[t]{8}{*}{ B30 } & $\mathrm{BP}$ & $\mathrm{kW}$ & $0.118 x-0.627$ & 0.777 \\
\hline & ME & $\%$ & $3.641 x-27.68$ & 0.988 \\
\hline & In-CPP & Bar & $0.19 x-1.335$ & 0.880 \\
\hline & BSFC & $\mathrm{kg} / \mathrm{kW}-\mathrm{s}$ & $-0.077 x+2.732$ & 0.924 \\
\hline & EGT & ${ }^{\circ} \mathrm{C}$ & $24.18 x-177.1$ & 0.988 \\
\hline & $\mathrm{CO}$ & $\%$ & $-0.006 x+0.14$ & 0.90 \\
\hline & $\mathrm{CO}_{2}$ & $\%$ & $0.379 x-4.067$ & 0.734 \\
\hline & $\mathrm{HC}$ & PPM & $-6 x+115.5$ & 0.952 \\
\hline \multirow[t]{8}{*}{ B40 } & $\mathrm{BP}$ & $\mathrm{kW}$ & $0.095 x-0.245$ & 0.836 \\
\hline & ME & $\%$ & $3.24 x-20.14$ & 0.990 \\
\hline & In-CPP & Bar & $0.169 x-1.052$ & 0.805 \\
\hline & BSFC & $\mathrm{kg} / \mathrm{kW}-\mathrm{s}$ & $-0.069 x+2.632$ & 0.426 \\
\hline & EGT & ${ }^{\circ} \mathrm{C}$ & $27.88 x-243.2$ & 0.967 \\
\hline & $\mathrm{CO}$ & $\%$ & $-0.004 x+0.105$ & 0.8 \\
\hline & $\mathrm{CO}_{2}$ & $\%$ & $0.1 x+0.45$ & 1.0 \\
\hline & $\mathrm{HC}$ & PPM & $-5.3 x+99.75$ & 0.997 \\
\hline
\end{tabular}

a higher compression ratio. Further, these could become a substitute for mineral diesel in the future.

\subsection{Future work}

Further experimental studies can be conducted to check the oxidation stability of the various dual biodiesel sample blends. The sample blends having better oxidation resistance can be further tested for their commercial viability.

Acknowledgements We are extremely grateful to the Division of Chemistry (Applied Sciences) and the Department of Mechanical Engineering (UIE), Chandigarh University, for providing the experimental facilities in their laboratories. 
Open Access This article is licensed under a Creative Commons Attribution 4.0 International License, which permits use, sharing, adaptation, distribution and reproduction in any medium or format, as long as you give appropriate credit to the original author(s) and the source, provide a link to the Creative Commons licence, and indicate if changes were made. The images or other third party material in this article are included in the article's Creative Commons licence, unless indicated otherwise in a credit line to the material. If material is not included in the article's Creative Commons licence and your intended use is not permitted by statutory regulation or exceeds the permitted use, you will need to obtain permission directly from the copyright holder. To view a copy of this licence, visit http://creativecommons. org/licenses/by/4.0/.

\section{References}

1. Acharya N, Nanda P, Panda S, Acharya S (2017) Analysis of properties and estimation of optimum blending ratio of blended mahua biodiesel. Eng Sci Technol an Int J 20:511-517. https://doi.org/10.1016/j.jestch.2016.12.005

2. Acharya N, Nanda P, Panda S, Acharya S (2019) A comparative study of stability characteristics of mahua and jatropha biodiesel and their blends. J King Saud Univ - Eng Sci 31:184-190. https://doi.org/10.1016/j.jksues.2017.09.003

3. Agarwal AK (2007) Biofuels (alcohols and biodiesel) applications as fuels for internal combustion engines. Prog Energy Combust Sci 33:233-271. https://doi.org/10.1016/j.pecs.2006. 08.003

4. Agarwal AK, Rajamanoharan K (2009) Experimental investigations of performance and emissions of Karanja oil and its blends in a single cylinder agricultural diesel engine. Appl Energy 86:106-112. https://doi.org/10.1016/j.apenergy.2008. 04.008

5. Ajala OE, Aberuagba F, Odetoye TE, Ajala AM (2015) Biodiesel: Sustainable energy replacement to petroleum-based diesel fuel - a review. ChemBioEng Rev 2:145-156. https://doi.org/ 10.1002/cben.201400024

6. Alptekin E, Canakci M (2008) Determination of the density and the viscosities of biodiesel-diesel fuel blends. Renew Energy 33:2623-2630. https://doi.org/10.1016/j.renene.2008.02.020

7. Asaithambi K, Krishnamoorthy R, Balasubramanian D (2020) A Comparative assessment of tailpipe emission characteristics on diesel engine using nanofluid with R-EGR setup. SAE Tech Pap. https://doi.org/10.4271/2020-28-0442

8. Ashraful AM, Masjuki HH, Kalam MA et al (2014) Production and comparison of fuel properties, engine performance, and emission characteristics of biodiesel from various non-edible vegetable oils: A review. Energy Convers Manag 80:202-228. https://doi.org/10.1016/j.enconman.2014.01.037

9. Atabani AE, Silitonga AS, Ong $\mathrm{HC}$ et al (2013) Non-edible vegetable oils: a critical evaluation of oil extraction, fatty acid compositions, biodiesel production, characteristics, engine performance and emissions production. Renew Sustain Energy Rev 18:211-245. https://doi.org/10.1016/j.rser.2012. 10.013

10. Balasubramanian D, Hoang AT, Papla Venugopal I et al (2021) Numerical and experimental evaluation on the pooled effect of waste cooking oil biodiesel/diesel blends and exhaust gas recirculation in a twin-cylinder diesel engine. Fuel. https://doi. org/10.1016/j.fuel.2020.119815

11. Balasubramanian R, Subramanian KA (2019) Experimental investigation on the effects of compression ratio on performance, emissions and combustion characteristics of a biodiesel-fueled automotive diesel engine. Biofuels. https:// doi.org/10.1080/17597269.2018.1558840

12. Bari S, Lim TH, Yu CW (2002) Effects of preheating of crude palm oil (CPO) on injection system, performance and emission of a diesel engine. Renew Energy 27:339-351. https://doi.org/ 10.1016/S0960-1481(02)00010-1

13. Bhale PV, Deshpande NV, Thombre SB (2009) Improving the low temperature properties of biodiesel fuel. Renew Energy 34:794-800. https://doi.org/10.1016/j.renene.2008.04.037

14. Channapattana SV, Kantharaj C, Shinde VS et al (2015) Emissions and Performance evaluation of $\mathrm{di} \mathrm{Cl}-\mathrm{VCR}$ engine fuelled with honne oil methyl ester /diesel blends. Energy Procedia 74:281-288. https://doi.org/10.1016/j.egypro.2015.07.606

15. Chauhan BS, Kumar N, Cho HM (2012) A study on the performance and emission of a diesel engine fueled with Jatropha biodiesel oil and its blends. Energy 37:616-622. https://doi. org/10.1016/j.energy.2011.10.043

16. Datta A, Mandal BK (2017) An experimental investigation on the performance, combustion and emission characteristics of a variable compression ratio diesel engine using diesel and palm stearin methyl ester. Clean Technol Environ Policy 19:1297-1312. https://doi.org/10.1007/s10098-016-1328-3

17. Devan PK, Mahalakshmi NV (2009) A study of the performance, emission and combustion characteristics of a compression ignition engine using methyl ester of paradise oil-eucalyptus oil blends. Appl Energy 86:675-680. https://doi.org/10.1016/j. apenergy.2008.07.008

18. Devarajan Y, Nagappan BK, Munuswamy DB (2017) Performance and emissions analysis on diesel engine fuelled with cashew nut shell biodiesel and pentanol blends. Korean J Chem Eng 34:1021-1026. https://doi.org/10.1007/s11814-016-0364-3

19. Dey AR, Misra RD (2017) Effect of infiltration of bio-lubricant on the performance of a compression ignition engine fuelled with biodiesel blends. Clean Technol Environ Policy 19:553-563. https://doi.org/10.1007/s10098-016-1247-3

20. El DG, Attia NK, Hawash SI (2009) Development and evaluation of biodiesel fuel and by-products from jatropha oil. Int J Environ Sci Technol 6:219-224. https://doi.org/10.1007/bf03327625

21. Dubey P, Gupta R (2017) Effects of dual bio-fuel (Jatropha biodiesel and turpentine oil) on a single cylinder naturally aspirated diesel engine without EGR. Appl Therm Eng 115:1137-1147. https://doi.org/10.1016/j.applthermaleng.2016.12.125

22. Dubey P, Gupta R (2018) Influences of dual bio-fuel (Jatropha biodiesel and turpentine oil) on single cylinder variable compression ratio diesel engine. Renew Energy 115:1294-1302. https://doi.org/10.1016/j.renene.2017.09.055

23. Dubey P, Gupta R (2016) Study of the performance and emission characteristics for a dual fuel powered single cylinder diesel engine. Int J Automot Mech Eng 13:3373-3388. https://doi.org/ 10.15282/ijame.13.2.2016.7.0279

24. El-Kassaby M, Nemit-Allah MA (2013) Studying the effect of compression ratio on an engine fueled with waste oil produced biodiesel/diesel fuel. Alexandria Eng J 52:1-11. https://doi.org/ 10.1016/j.aej.2012.11.007

25. Elumalai PV, Balasubramanian D, Parthasarathy M et al (2021) An experimental study on harmful pollution reduction technique in low heat rejection engine fuelled with blends of pre-heated linseed oil and nano additive. J Clean Prod. https://doi.org/10. 1016/j.jclepro.2020.124617

26. Fayyazbakhsh A, Pirouzfar V (2017) Comprehensive overview on diesel additives to reduce emissions, enhance fuel properties and improve engine performance. Renew Sustain Energy Rev 74:891-901. https://doi.org/10.1016/j.rser.2017.03.046

27. Graboski MS, McCormick RL (1998) Combustion of fat and vegetable oil derived fuels in diesel engines. Prog Energy Combust Sci 24:125-164. https://doi.org/10.1016/S0360-1285(97)00034-8 
28. Ingle PB, Ambade RS, Paropate RV, Bhansali SS (2011) Comparisons of diesel performance neat andpreheated transesterfied cotton seed oil. Int J Adv Eng Sci Technol 5:67-71

29. Khalil I, Aziz ARA, Yusup S et al (2017) Response surface methodology for the optimization of the production of rubber seed/ palm oil biodiesel, IDI diesel engine performance, and emissions. Biomass Convers Biorefinery 7:37-49. https://doi.org/10. 1007/s13399-016-0221-y

30. Krishnamoorthy R, Asaithambi K, Balasubramanian D et al (2020) Effect of cobalt chromite on the investigation of traditional $\mathrm{Cl}$ engine powered with raw citronella fuel for the future sustainable renewable source. SAE Tech Pap. https://doi.org/10.4271/ 2020-28-0445

31. Mahdavi M, Abedini E, Darabi AH (2015) Biodiesel synthesis from oleic acid by nano-catalyst ( $\mathrm{ZrO} 2 / \mathrm{Al} 2 \mathrm{O} 3)$ under high voltage conditions. RSC Adv 5:55027-55032. https://doi.org/10.1039/ c5ra07081c

32. Mathew A, Anand K (2018) Comparison of engine characteristics with biodiesels produced from fresh and waste cooking oils. Biofuels. https://doi.org/10.1080/17597269.2018.1519761

33. Muralidharan K, Vasudevan D (2011) Performance, emission and combustion characteristics of a variable compression ratio engine using methyl esters of waste cooking oil and diesel blends. Appl Energy 88:3959-3968. https://doi.org/10.1016/j. apenergy.2011.04.014

34. Nagaraja S, Sakthivel M, Sudhakaran R (2012) Comparative study of the combustion, performance, and emission characteristics of a variable compression ratio engine fuelled with diesel, corn oil methyl ester, and palm oil methyl ester. J Renew Sustain Energy. https://doi.org/10.1063/1.4768543

35. Nagaraja S, Sakthivel M, Sudhakaran R (2013) Combustion and performance analysis of variable compression ratio engine fueled with preheated palm oil - diesel blends. Indian J Chem Technol 20:189-194

36. Nagaraja S, Sooryaprakash K, Sudhakaran R (2015) Investigate the effect of compression ratio over the performance and emission characteristics of variable compression ratio engine fueled with preheated palm oil - diesel blends. Procedia Earth Planet Sci 11:393-401. https://doi.org/10.1016/j.proeps.2015.06.038

37. Örs İ, Sarıkoç S, Atabani AE, Ünalan S (2019) Experimental investigation of effects on performance, emissions and combustion parameters of biodiesel-diesel-butanol blends in a direct-injection $\mathrm{Cl}$ engine. Biofuels. https://doi.org/10.1080/17597269.2019. 1608682

38. Parthasarathy M, Ramkumar S, Isaac JoshuaRamesh Lalvani J et al (2020) Performance analysis of $\mathrm{HCCl}$ engine powered by tamanu methyl ester with various inlet air temperature and exhaust gas recirculation ratios. Fuel. https://doi.org/10.1016/j. fuel.2020.118833

39. Rahman SMA, Masjuki HH, Kalam MA et al (2013) Production of palm and Calophyllum inophyllum based biodiesel and investigation of blend performance and exhaust emission in an unmodified diesel engine at high idling conditions. Energy Convers Manag 76:362-367. https://doi.org/10.1016/j.encon man.2013.07.061

40. Rajak U, Verma TN (2018) Effect of emission from ethylic biodiesel of edible and non-edible vegetable oil, animal fats, waste oil and alcohol in $\mathrm{Cl}$ engine. Energy Convers Manag 166:704718. https://doi.org/10.1016/j.enconman.2018.04.070

41. Ramalingam K, Balasubramanian D, Chellakumar PJTJS et al (2020) An assessment on production and engine characterization of a novel environment-friendly fuel. Fuel. https://doi.org/ 10.1016/j.fuel.2020.118558

42. Reddy GV, Rasu NG, Prasad TH (2017) Experimental investigation on the performance of $\mathrm{Cl}$ engine using dual biodiesel.
International conference 21st century energy needs - Mater Syst Appl ICTFCEN 2016. https://doi.org/10.1109/ICTFCEN.2016. 8052733

43. Ruhul AM, Kalam MA, Masjuki HH et al (2016) Production, characterization, engine performance and emission characteristics of Croton megalocarpus and Ceiba pentandra complementary blends in a single-cylinder diesel engine. RSC Adv 6:2458424595. https://doi.org/10.1039/c5ra21750d

44. Salam S, Choudhary T, Pugazhendhi A et al (2020) A review on recent progress in computational and empirical studies of compression ignition internal combustion engine. Fuel. https://doi. org/10.1016/j.fuel.2020.118469

45. Sandouqa A, Al-Hamamre Z (2019) Energy analysis of biodiesel production from jojoba seed oil. Renew Energy 130:831-842. https://doi.org/10.1016/j.renene.2018.07.015

46. Saravanan A, Murugan M, Sreenivasa Reddy M, Parida S (2020) Performance and emission characteristics of variable compression ratio $\mathrm{Cl}$ engine fueled with dual biodiesel blends of Rapeseed and Mahua. Fuel. https://doi.org/10.1016/j.fuel.2019. 116751

47. Sharma Dugala N, Singh Goindi G, Sharma A (2020) Evaluation of physicochemical characteristics of Mahua (Madhuca indica) and Jatropha (Jatropha curcas) dual biodiesel blends with diesel. J King Saud Univ - Eng Sci. https://doi.org/10.1016/j.jksues.2020. 05.006

48. Shrivastava P, Verma TN (2020) Effect of fuel injection pressure on the characteristics of $\mathrm{Cl}$ engine fuelled with biodiesel from Roselle oil. Fuel. https://doi.org/10.1016/j.fuel.2019.117005

49. Shrivastava P, Verma TN, David Samuel O, Pugazhendhi A (2020) An experimental investigation on engine characteristics, cost and energy analysis of $\mathrm{Cl}$ engine fuelled with Roselle. Karanja biodiesel and its blends Fuel. https://doi.org/10.1016/j.fuel. 2020.117891

50. Shrivastava P, Verma TN, Pugazhendhi A (2019) An experimental evaluation of engine performance and emisssion characteristics of $\mathrm{Cl}$ engine operated with Roselle and Karanja biodiesel. Fuel. https://doi.org/10.1016/j.fuel.2019.115652

51. Singh TS, Verma TN (2019) Biodiesel production from Momordica Charantia (L.): extraction and engine characteristics. Energy 189:116198. https://doi.org/10.1016/j.energy.2019.116198

52. Sivaramakrishnan K (2018) Investigation on performance and emission characteristics of a variable compression multi fuel engine fuelled with Karanja biodiesel-diesel blend. Egypt J Pet 27:177-186. https://doi.org/10.1016/j.ejpe.2017.03.001

53. Solaimuthu C, Govindarajan P (2015) Performance evaluation of a urea-water selective catalytic reduction (SCR) for a diesel engine with mahua bio diesel. Energy Sources, Part A Recover Util Environ Eff 37:1424-1431. https://doi.org/10.1080/15567 036.2011 .621012

54. Srinivasa Rao M, Anand RB (2015) Production characterization and working characteristics in $\mathrm{DICl}$ engine of Pongamia biodiesel. Ecotoxicol Environ Saf 121:16-21. https://doi.org/10. 1016/j.ecoenv.2015.07.031

55. Srithar K, Balasubramanian KA (2014) Dual biodiesel for diesel engine -Property, performance and emission analysis. Int Energy J 14:107-120

56. Thoai DN, Tongurai C, Prasertsit K, Kumar A (2019) Review on biodiesel production by two-step catalytic conversion. Biocatal Agric Biotechnol. https://doi.org/10.1016/j.bcab.2019.101023

57. Vallinayagam R, Vedharaj S, Yang WM et al (2014) Pine oil-biodiesel blends: a double biofuel strategy to completely eliminate the use of diesel in a diesel engine. Appl Energy 130:466-473. https://doi.org/10.1016/j.apenergy.2013.11.025

58. Verma TN, Nashine P, Chaurasiya PK et al (2020) The effect of ethanol-methanol-diesel-microalgae blends on performance, combustion and emissions of a direct injection diesel engine. 
Sustain Energy Technol Assess. https://doi.org/10.1016/j.seta. 2020.100851

59. Wakil MA, Kalam MA, Masjuki HH et al (2015) Influence of biodiesel blending on physicochemical properties and importance of mathematical model for predicting the properties of biodiesel blend. Energy Convers Manag 94:51-67. https://doi.org/ 10.1016/j.enconman.2015.01.043

60. Yasin MHM, Mamat R, Yusop AF et al (2013) Fuel physical characteristics of biodiesel blend fuels with alcohol as additives. Procedia Eng 53:701-706. https://doi.org/10.1016/j.proeng.2013.02. 091
61. Zhu L, Xiao Y, Cheung CS et al (2016) Combustion, gaseous and particulate emission of a diesel engine fueled with $n$-pentanol (C5 alcohol) blended with waste cooking oil biodiesel. Appl Therm Eng 102:73-79. https://doi.org/10.1016/j.appltherma leng.2016.03.145

Publisher's Note Springer Nature remains neutral with regard to jurisdictional claims in published maps and institutional affiliations. 